Geo-Marine Letters

December, 2006 Volume 26, Number 6 / : 347-359

http://dx.doi.org/ 10.1007/s00367-006-0044-0

(C)2006 Springer Science+Business Media

The original publication is available at http://www.springerlink.com
Archimer, archive institutionnelle de l'Ifremer http://www.ifremer.fr/docelec/

\title{
Quaternary turbidite systems on the northern margins of the Balearic Basin (Western Mediterranean): a synthesis
}

\author{
L. Droz ${ }^{1,{ }^{\star}}$, A. T. dos Reis ${ }^{2}$, M. Rabineau ${ }^{1}$, S. Berné $^{3}$ and G. Bellaiche ${ }^{4}$
}

(1) CNRS, UMR 6538, Institut Universitaire Européen de la Mer, Place Nicolas Copernic, 29280 Plouzané, France

(2) Departamento de Oceanografia/UERJ-Brazil, Rua São Francisco Xavier 524, 4 Andar, Maracanã, Rio de Janeiro, 22550-900 RJ, Brazil

(3) IFREMER, Laboratoire Environnements Sédimentaires, 29280 Plouzané, France

(4) CNRS, UMR 6526 GEOSCIENCES-AZUR, B.P. 48, 06235 Villefranche/Mer, France

*: Corresponding author : Email: Idroz@univ-brest.fr; Phone: +33-2-98498734; Fax: +33-2-98498760

\begin{abstract}
:
The Balearic Basin is a young basin composed of thick Plio-Quaternary sediments, including active gravity sedimentation. During the Quaternary, gravity processes deposited (1) turbidite systems, either as symmetrical fans (Petit-Rhône and Valencia fans) or asymmetrical ridges (Marseille-Planier, Grand-Rhône and Pyreneo-Languedocian ridges) and (2) several mass-transport deposits, indicating recurrent sedimentary failures of the margin. This paper synthesizes previous works and proposes a chronological sedimentary evolution for the basin. Except for the last $20 \mathrm{ka}$, the chronostratigraphy remains poorly constrained but should soon be established for the last $500 \mathrm{ka}$, based on the PROMESS1 drillings on the outer shelf of the Gulf of Lions, and hopefully for the last $30 \mathrm{Ma}$, based on ultra-deep drilling in the deep basin from aboard the Chikyu research vessel (IODP proposal Pre699).
\end{abstract}




\section{I-Introduction}

The Gulf of Lions is a young passive margin which, because of a high total subsidence rate (250 $\mathrm{m} / \mathrm{Ma}$ on the outer shelf on the Aude-Hérault interfluve; Rabineau 2001), is very favourable for the registration and preservation of sedimentary sequences from the source (mainly the Rhône River) to the sink (the turbidite sequences in the basin) including the deposition and stacking of strata on the shelf and in the canyons. Since the first publication on the Rhône Deep-Sea Fan (Menard et al. 1965), data acquisition and researches on the Plio-Quaternary sedimentation of the Gulf of Lions have been continuous, especially since the 70s', resulting in a large geological and geophysical data base that places the Gulf of Lions among the best known margins in the world. Numerous mainly French and Spanish laboratories have been and are currently involved in these researches, including the sedimentological laboratories of the University of Paris 6 at Villefranche/Mer and Paris, the University of Perpignan, the University of Brest (UBO), Ifremer, the Spanish CNR in Barcelona and the University of Barcelona. A synthesis of these works was proposed by dos Reis et al. (2005) at the scale of the Plio-Quaternary, highlighting the tectonic and halokinetic control on sedimentation.

Recently, special research efforts on the sedimentation in the Gulf of Lions have been brought by the objectives of French and European programmes, including the French GDR Marges (http://gdrmarges.lgs.jussieu.fr) items "Gulf of Lions" and "Siliciclastic and Carbonated Turbidites" and EU projects EUROSTRATAFORM (http://www.soc.soton.ac.uk/CHD/EUROSTRATAFORM) and PROMESS1 (http://promess1.wdc-mare.org). In the framework of these programmes, new data are currently acquired in an effort to obtain key results on sedimentary systems from source to sink on the time-scale of $500 \mathrm{ka}$, including chronostratigraphic markers and physical parameters on hydrodynamic processes.

This paper aims to present a synthesis devoted to the recent (Quaternary) evolution of sedimentary systems around the Balearic Basin of the Western Mediterranean (Fig. 1) with special emphasis on the Gulf of Lions, in order to propose a general framework for newly acquired results.

\section{II-Tectonic, climatic and eustatic history of the margin}

The margin is related to large-scale Oligocene extension coeval with the counter clockwise rotation of the Corsican-Sardinian block (Olivet 1996). This rotation has recently been dated between 21 and $15 \mathrm{Ma}$ (Speranza et al. 2002).

The evolution of the margin led to deposition of thick (several kilometres) marine deposits both on the shelf and on the slope and deep basin from the end of the Miocene to the present. Three major periods characterize this sedimentation: the Messinian Salinity Crisis, the rapid Lower Pliocene sea level rise and the marked climatic cycles during the Upper Pliocene to Quaternary times that lead to cyclic sea-level variations.

\section{The Messinian salinity crisis}

Marine deposition was interrupted around 5.5 Ma by an important episode of lowering of sea level and consecutive emersion of the margins of the Mediterranean during the Messinian Salinity Crisis. During this period, the Evaporites Sequence was deposited in the basin, while the margins were severely eroded. The Evaporites Sequence has been partly drilled during DSDP Legs 13 (Ryan et al. 1973) and 42A (Hsü et al. 1978) and ODP Leg 161 (Comas et al. 1999): it is composed of, from top to bottom, (i) the upper evaporites, of seismically very high amplitude stratified facies, composed of halite, gypsum and marls), (ii) the salt layer, with a transparent seismic facies made of halite, and (iii) the lower evaporites that were never drilled but are possibly of the same composition as the upper evaporites, due to seismic facies similarities Erosion of the emerged margins resulted in the Messinian Unconformity on the shelf and slope, truncating the pre-salt marine series (Burdigalian to Tortonian), and the incision of land-connected deep canyons on the continental shelf and upper slope (Gorini 1993; Gorini et al. 2005; Lofi et al. 2005) that funnelled products of erosion towards the basin while at the same time the lower evaporites were deposited in the deep basin. 


\section{The Lower Pliocene rise of sea-level}

The paleomorphology at the end of the Messinian was very similar to that observed at present except for the exceptionally low sea-level (of the order of $1000 \mathrm{~m}$ ). Following this major lowstand event, the re-opening of the Strait of Gibraltar during the Lower Pliocene, together with the global Pliocene rise of sea-level (DSDP Leg 13, Ryan et al. 1973) resulted in a major high sea-level well above the present-day sea-level (about $70 \mathrm{~m}$ according to Clauzon et al. 1995). The ensuing high sealevel lasted about 1 Ma.

Depending on the morphology of the borderlands, the sea entered widely on former land areas and formed deep rias of various lengths inside the main rivers of the margin (for example reaching Lyon in the Rhône ria, $260 \mathrm{~km}$ upslope from the present-day shore line). The combination of the Messinian fluvial incision and the unusually high sea level of the Lower Pliocene led to a very specific paleo-geography with no shelves, deeply incised rias, narrow and deep marine basins fed by a mountainous hinterland with high relief and a high sediment supply (Clauzon et al. 1995). Infilling of the rias was realised by prograding Gilbert-type fan-deltas (Clauzon et al. 1995), while the deepest part of the Mediterranean basin was the site of condensed deposition, characterized by thin marine shales enriched with planktonic elements (DSDP Leg 13, site 132, Ryan et al. 1973).

\section{The Upper Pliocene to Quaternary glacio-eustatic fluctuations}

Extreme climatic modifications generated by fluctuations of ice development in the Northern Hemisphere followed the anomalous Lower Pliocene event. Upper Pliocene to Quaternary sedimentation became mainly controlled by glacio-eustatic sea-level changes related to the Milankovitch cyclicities. During the Pleistocene the dominant cyclicity changed (from 40 ka to 100 ka) and was accompanied by a change in sea-level cycle amplitudes (from $50 \mathrm{~m}$ to $100 \mathrm{~m}$ ). This change, called the Mid-Pleistocene Revolution, generally occurs at stage 22 (around 800-900 ka, e.g. Paillard 2001; Ruddiman et al. 1986). Sedimentation in the Gulf of Lions became dominated by terrigeneous deposition brought from the main rivers to the basin (Fig 1) through turbidite systems. Sedimentary input principally originated from the Alps that were drained by the Rhône River and its tributaries. Input from the Massif Central (Chamley 1971) and Pyrenees remained low. Quaternary fluvial erosion was powerful, as attested by the depth of the rivers and was variably enhanced by continental uplift (Clauzon et al. 1995).

The absence of detailed chronostratigraphic data in the Gulf of Lions is a great gap for the full understanding of its sedimentary evolution and of the factors that control this evolution. Industrial borehole GLP1 (e.g. in ; Droz 1999; dos Reis 2001; dos Reis et al. 2005) provided the depth of the Pliocene/Pleistocene boundary that was correlated regionally on industrial HR multichannel seismic profiles (see Fig. 1 for location of GLP1). On seismic sections, Pliocene turbidites are identified at the base of slope, under the Petit-Rhône Fan (Droz 1991) and all along the margin (dos Reis 2001; dos Reis et al. 2005) as small channel/levee systems grouped into a basal complex of channelized units, with little architectural organisation and distal seismic character when compared to the Quaternary deposits (see below). Droz and Bellaiche (1985) proposed that the huge Pleistocene channel/levee complexes on top of the distal Pliocene turbidites at the base of slope was related to a strong progradation of the margin during the Quaternary, as expected from glacio-eustatic changes of sealevel. Pliocene turbidites probably used previous Messinian canyons/fluvial incisions observed on the isochron and isobath map of the Messinian surface (Gorini 1993; Guennoc et al. 2000; Gorini et al. 2005). The initiation of turbidite deposition during the Pliocene is not age-constrained, but probably occurred early as suggested by their identification close to the Messinian upper evaporites (Droz 1991). The thickening of Pliocene sediments down slope from the Marti Canyon and Rhône Canyon (dos Reis, unpublished data) attests that they were dominant input paths to the basin at that time. 


\section{III- Quaternary gravity sedimentation of the northern Balearic Basin}

During the Quaternary, the Gulf of Lions' slope and rise have been the site of thick sedimentary accumulations deposited by gravity processes (dos Reis 2001; Droz 1991) (Fig. 2). Several huge allochtonous unconformable transparent bodies interpreted as mass-transport deposits also attest to the importance of repeated periods of instability during the Quaternary.

\section{Present-day morphology of the shelf and slope of the Gulf of Lions}

The newly published bathymetric map of the Gulf of Lions (Berné et al. 2001) together with the interpretation of seismic data enabled a detailed morpho-sedimentary description of the margin and an origin for the observed sedimentary features (Berné et al. 2002). The shelf of the Gulf of Lions is 80 $\mathrm{km}$ wide in its central part and less than $20 \mathrm{~km}$ wide at its western and eastern limits. The outer shelf is affected by two main types of topographical features that are markers of sea-level changes during and after the Last Glacial Maximum (LGM): (i) a shore parallel main break in slope of regional extent occurs from 98-112 m (depending on the location on the shelf) down to about 120-128 m creating a clear and continuous step, which is interpreted as isotopic stage 2 sandy shoreline remnants; (ii) shore transverse elongated features, either lows or bulges, are representative of the retreat path of paleo-river courses during the deglacial sea-level rise (Torres 1995; Rabineau 2001; Marsset and Bellec 2002; Berné et al. 2001, 2002). During the LGM, the Petit-Rhône River was connected to the Petit-Rhône, Marti and Hérault Canyons, and the Pyrenean Rivers were connected to the Aude (also called Bourcart) and Lacaze-Duthiers Canyons to the west (Figs. 1, 3). The connection of rivers has also been demonstrated by Baztan (2004) and Baztan et al. (2005) by the existence of an active axial incision in the Marti, Hérault, Aude, Lacaze-Duthiers and Cap Creus canyons.

The continental slope is characterized by strong incisions by canyons (Fig. 3). Three groups of canyons can be distinguished:

(i) To the west, the Pyreneo-Languedocian canyons (Cap Creus, Lacaze-Duthiers, Pruvost, Aude, Hérault Canyons from west to east) and Marti and Catherine-Laurence Canyons form a converging network that joins the Sète Canyon at various depth. Seismic data revealed that these canyons were more or less parallel to each other and oriented approximately N-S, parallel to the slope gradient during the Early Quaternary and that the converging pattern presently observed was acquired recently (very Late Pleistocene, maybe between $150 \mathrm{ka}$ and $20 \mathrm{ka}$ ) (Droz et al. 1998; dos Reis et al. 2005). In the basin, the Pyreneo-Languedocian Canyons fed an asymmetrical turbidite system, the Pyreneo-Languedocian Ridge.

(ii) To the east of the Gulf of Lions, the Grand-Rhône, Marseille/Planier and Cassidaigne Canyons (from west to east) are NW-SE oriented and are followed at the base of slope by nearly W-E valleys that are bordered on their right hand side by elongated ridges of turbidite origin.

(iii) In the central part, between these two groups of canyons, the Petit-Rhône Canyon has a contrasting morphology with a meandering inner erosional thalweg along its entire length. Meandering inner thalwegs are not known elsewhere in the Gulf of Lions, except in the very upper course of the Aude Canyon where a meandering axial incision is present (Berné et al. 2002; Gaudin et al. 2003; Baztan et al. 2005). The Petit-Rhône Canyon, presently connected to the Neochannel (see below), has been the only path for feeding alpine detritic material towards the Petit-Rhône Deep Sea Fan during the Quaternary.

\section{The turbidite systems in and around the Balearic Basin}

Two thick turbidite systems, the Petit-Rhône Fan and the Pyreneo-Languedocian Ridge, observable on the isopach map of the Quaternary of the Gulf of Lions (Fig. 2; dos Reis 2001; dos Reis et al. 2005) face the main rivers outlets of the French Mediterranean margin.

\section{The Petit-Rhône Fan}

The Petit-Rhône Fan (Droz 1983, 1991; Coutellier 1985; Torres 1995; dos Reis 2001; Droz and Bellaiche 1985) is the largest turbidite system in the Gulf of Lions. Situated in the central part of the Gulf, it represents an accumulation of $3600 \mathrm{~m}$ of turbidites and mass-transport deposits, the 
Quaternary fan being about 1300 m thick (Fig. 2). The fan was fed mainly by alpine inputs through the Rhône River and Delta and the Petit-Rhône canyon.

The Quaternary Petit-Rhône Fan is an overall symmetrical feature extending to at least $2850 \mathrm{~m}$ water depth where channels have been imaged (Droz et al. 2003). At $2750 \mathrm{~m}$ water depth, cores sampled coarse turbidites (Méar 1984). The fan is composed of stacked channel/levee systems characterized by typical lens shaped seismic bodies associated to stratified facies in levees and high amplitude chaotic facies in a central channel. The channel/levee systems are grouped into three main complexes (1-lower, 2-middle and 3-upper complexes from the oldest to the youngest) overlapping each other while avulsing westwards, and shows a basinward divergent architecture from a common landward point source, the Petit-Rhône Canyon (Fig. 3). Although absolute ages are not available for these turbidite complexes, they are supposed to accumulate during Quaternary lowstands of sea level. Based on this assumption and on the paleodrainage reconstruction on the shelf during the Quaternary (Monjuvent 1984), a chronostratigraphic history was proposed by Bellaiche et al. (1989) that places the transition from the middle complex to the upper complex during the Mindel/Riss interglacial, i.e. a high sea-level dated between 200 to $500 \mathrm{ka}$, depending on correlations between continental and marine studies (Van Eysinga and Haq 1987; Kukla and Cilek 1996).

During the Late Quaternary, the Rhône Fan underwent a last westward avulsion of its main channel and built partly on its right levee and partly on a transparent mass-transport body (see below) the lobate Neofan (Droz and Bellaiche 1985; Torres et al. 1997) (Fig. 4). The Neofan includes 2 main units (Bonnel 2001; Bonnel et al. 2005), a basal one (the Neofan Chaotic Unit) made of high amplitude seismic facies of about $50 \mathrm{~m}$ of thickness, interpreted as an avulsion lobe similar to the HARPs of the Amazon Fan (e.g. Pirmez et al. 1997), and an upper unit (the Neofan Transparent Unit) about $30 \mathrm{~m}$ thick, representing a small channel/levee system, seismically transparent on sparker data, and stratified on chirp data, that prograded on its avulsion lobe (Fig. 4). The Neofan extends southwestwards for at least $100 \mathrm{~km}$ down from the Neochannel bifurcation point to a distal area where several generations of lobate features interpreted as terminal lobes are present (Droz et al. 2004). The sea-floor on the western part of the Neofan is affected by giant scours that are erosional features typical of a channel/lobe transition zone according to Kenyon et al. (1995) and are supposed to originate from hydraulic jump processes of the turbidity currents at the termination of the Neochannel (Kenyon et al. 1995; Bonnel et al. 2005).

AMS radiocarbon dating indicates that the starvation of the Neofan occurred at 15.1 ka B.P. (in this paper all the ages younger than about $20 \mathrm{ka}$ are expressed in ${ }^{14} \mathrm{C}$ time scale; Table 1 provides the corresponding calibrated ages and reservoir correction age when known) when it became inactive. Upstream of the avulsion point, the starvation and inactivity of the fan seems to occur 4 ka later at 11 ka B.P (Bonnel et al. 2005). The onset of the Neofan is still unknown as it is too thick $(\sim 80 \mathrm{~m}$ ) to be reached by conventional coring. From pollen analysis in a core located on the right levee of the Neochannel, Beaudouin et al. (2004) provided an estimated age of 18.6 ka B.P. at $8.5 \mathrm{~m}$ inside the upper unit of the Neofan that allowed Bonnel et al. (2005) to calculate a mean deposition rate ( $1 \mathrm{~m} / \mathrm{ka}$ ) and a linearly extrapolated maximum age of $100 \mathrm{ka}$ B.P. for the occurrence of the avulsion and beginning of growth of the Neofan. However, turbidite deposition rate is not linear but is highly discontinuous with short periods of accelerated deposition (for example up to 3 to $4 \mathrm{~m} / \mathrm{ka}$ in the Amazon Fan according to Showers et al. 1997) alternating with periods of slower hemipelagic deposition. Therefore the use of mean deposition rates is highly unreliable, and the proposed age is probably greatly overestimated. Previously, Méar (1984) had indicated that turbidite sedimentation on levees stopped at about $20 \mathrm{ka}$ B.P. in water depths greater than $2000 \mathrm{~m}$, i.e. downslope from the Neochannel bifurcation point. This starvation of the fan beyond $-2000 \mathrm{~m}$ possibly relates to the shift of the Petit-Rhône fan depocenters towards the Neofan. Admitting this age as indicative of the approximate onset of the Neofan, a much higher mean deposition rate is calculated $(16 \mathrm{~m} / \mathrm{ka})$ that is also not accurate, but is probably closer to the real deposition rate of the avulsion lobe that accounts for more than $60 \%$ of the Neofan thickness. 


\section{The Pyreneo-Languedocian Ridge}

In the western corner of the Gulf of Lions, the Pyreneo-Languedocian Ridge is a 900-1000 m thick sediment accumulation at the base of the western slope that connects with the PyreneoLanguedocian plus the Marti and Catherine-Laurence Canyons (Fig. 3).

Berné et al. (1999) and Droz et al. (2001) proposed that the Pyreneo-Languedocian Ridge is an asymmetrical feature located on the right-hand side of the Sète Valley, with strong similarities to the Var Ridge on the Provençal margin (Savoye et al. 1993) and was fed by sediment funnelled in the converging network of the Pyreneo-Languedocian canyons. More recently, dos Reis et al. (2004a, 2005) considered a two-stage building, an early fan-like building period, in relation to the abandoned $\mathrm{N}-\mathrm{S}$ lower courses of the Pyreneo-Languedocian canyons and a later asymmetrical ridge-like building by overflow from the Sète Canyon receiving the Pyreneo-Languedocian canyons.

Shelf studies have shown that detritic sediments were supplied to the ridge partly by the Pyreneo-Languedocian rivers (Tech, Têt, Agly, Aude, Orb, Hérault, from southwest to northeast), and partly the Rhône River that not only fed the Petit-Rhône canyon but also the Marti Canyon and maybe the Hérault canyon during the LGM (Berné et al. 1999, 2002). According to Baztan (2004) the Sète canyon has also been connected to the Rhône River.

The Pyreneo-Languedocian complex is restricted in space, extending from about 2000 to 2500 m water depth, over approximately $50 \mathrm{~km}$ in a NW-SE direction. It is made of stratified undulating seismic facies interpreted as migrating sediment waves (e.g. Jallet and Giresse 2005) that aggraded vertically all along the Quaternary, the Sète valley undergoing only a faint progressive lateral migration towards the east. Although direct dating information are lacking, geometrical relationships from seismic profiles indicate that building of the ridge was probably contemporaneous to the upper complex of the Petit-Rhône Fan and therefore is inferred to be Upper Pleistocene in age (Bellaiche et al. 1989), i.e. around 200-500 ka. In contrast to the Petit-Rhône Fan, no channel/levee systems are observable during the Pliocene, suggesting that the activity of the Pyreneo-Languedocian canyons began later than the Petit-Rhône Canyon and Deep Sea Fan.

The area located at the outlet of the Sète and La Fonera Canyons (on the Catalan Margin) remained active very late during the Quaternary (Late Pleistocene-Holocene), while the Petit-Rhône Fan and Neofan were already abandoned (Droz et al. 2001). This recent activity is highlighted by thin low backscattering patchy lobes at the outlet of both canyons, in which cores recovered beds of silts to fine sands intercalated within a $2.3 \mathrm{~m}$ thick unit of foraminiferal and nannofossils oozes (Bonnel et al. 2005). In both cases, the hemipelagic unit was deposited since the abandonment of the Neofan at 15.1 ka B.P. and radio-carbon ages at the top of the hemipelagic unit (2.5 ka B.P.) allowed estimation of an age of 8 ka B.P. in the Sète Lobe and 4 ka B.P. in the La Fonera Lobe for the last events of sand deposition, by linear interpolation using mean sedimentation rates (Bonnel et al. 2005) (Figs. 3 and 5).

\section{Other turbidite systems around the Balearic Basin}

\section{Eastern part of the Gulf of Lions and Provençal margin.}

At the eastern corner of the Gulf of Lions, the Grand-Rhône, Marseille/Planier and Cassidaigne Canyons from west to east, gave rise to elongated turbidite ridges (Droz 1991; dos Reis 2001; dos Reis et al. 2004b), extending for up to $90 \mathrm{~km}$ parallel to the south Provençal margin. Except for the Cassidaigne Canyon, which does not have a clear relationship with a river, both the other canyons were fed with Alpine detrital input from the Grand-Rhône outlet of the Rhône River, to the East of the Petit-Rhône outlet. The lower course of the canyons are deflected towards the east, in response to halokinetic controls (dos Reis et al. 2004b) rather than coriolis controls and bordered on their southern side by the ridges.

Detailed analysis of the architecture of the ridges showed that the current highly asymmetrical ridge-like morphology is salt-tectonically imposed and not hydrodynamically dependent and therefore is not representative of the true architectural style of the depocenters. dos Reis et al. (2004b) showed that along the Marseille/Planier Valley, overbanking of turbidity currents occurred on both sides, but that, on the northern side, syn-sedimentary activity of growth faults created hemi-grabens which 
trapped turbidites, preventing the typical levee morphology from developing on the left levee. The left levee of the Grand-Rhône Valley was also shown to be inhibited by a local buttress provided by the prominent Marseille sedimentary ridge, up to about $600 \mathrm{~m}$ high.

\section{Eastern Iberian margin.}

To the west of the Balearic Basin, short canyons and gullies are cut into the continental shelf and slope of the Catalan margin (Amblas et al. 2004), but no thick turbidite systems are described. The main river that delivered sediments to the basin is the Ebro River (Fig. 1) that contributed to the building of a turbidite system made of short channel/levee systems, debris flows and apron deposits on the upper slope of the Ebro margin (Alonso and Maldonado 1990; Alonso and Ercilla 2002; Alonso et al. 1991).

The main deep turbidite system on the eastern Iberian margin is the Valencia Fan. The Valencia Valley has a tectonically controlled southwest/northeast course, between the Iberian continental slope and the Balearic Islands until it merges into the open Balearic Basin where it is deflected toward the southeast (Figs. 1, 3). The Valencia Valley is not connected to a river but collects inputs from tributaries that dissect the Iberian margin on its northern side, including the Ebro inputs.

The Valencia Valley is a long leveed valley of the mid-ocean submarine valley type (Canals et al. 2000) that ends with a terminal lobe on the Balearic Plain east of the Minorca Island (Palanques et al. 1995). The Valencia lobe extends more than $150 \mathrm{~km}$ downdip and is a maximum of $25 \mathrm{~km}$ across (Fig. 3). Although not dated, it appears to be a very recent feature (Late Pleistocene-Holocene) as suggested by fresh bedforms and erosional features and sandy turbidites containing pteropod shells of Holocene age, recovered in cores (Morris et al. 1998).

\section{Mass-movement deposits}

In addition to the turbidite systems, gravity deposits are present on the northern and western margins of the Balearic Basin, as broad and thick (up to $75 \mathrm{~m}$ thick for a volume of up to $200 \mathrm{~km}^{3}$ ) unconformable transparent mass-transport deposits.

In the Gulf of Lions, the western and eastern mass-transport bodies (representing an estimated total volume of $370 \mathrm{~km}^{3}$ ) truncate both levees of the Petit-Rhône Fan (Bellaiche et al. 1986) (Figs. 3, 4). The western mass-transport body extends along $150 \mathrm{~km}$ at the base of the Gulf of Lions slope between the Pyreneo-Languedocian Ridge and the Petit-Rhône Fan. It is up to 120 ms two-way time (about $100 \mathrm{~m}$ ) thick in its upslope part and represents an estimated volume of $217 \mathrm{~km}^{3}$. Because of its transparent seismic facies, erosional basal surface and allochtonous origin, this mass-transport body is interpreted as a debris flow and was previously named the "Western Debris-Flow" (Droz and Bellaiche 1985). Direct dating is not yet available for this body. However, it is intercalated between the Petit-Rhone Fan (below) and the Neofan (above). Considering that its onset has been most likely of very short duration (instantaneous at the geological time scale), we can infer that instability processes occurred around 20 ka B.P., between the end of activity of the Petit-Rhône Fan south from the Neochannel bifurcation point (Méar 1984) and the onset of the Neofan (see above).

On the Ebro Margin, the Columbretes Slide (Field and Gardner 1990) later renamed the Big'95 debris flow by Canals et al. (2000) and Lastras et al. (2002) is identified on sub bottom profiles as a transparent sediment body located on the Ebro slope, base of slope and inside the Valencia Valley. This transparent body shows thickness ranging from $153 \mathrm{~m}$ near the source area to less than $15 \mathrm{~m}$ in its distal depositional area and extends over a surface of about $2000 \mathrm{~km}^{2}$ involving a sediment volume greater than $26 \mathrm{~km}^{3}$ (Lastras et al. 2002, 2004). From radio-carbon dating, the minimum age of the debris flow is about $10.3 \mathrm{ka}$ B.P. Other indications of recent instability processes are also mentioned on both sides of the Valencia Valley by Alonso et al. (1995).

Altogether, these allochtonous bodies, of Late Quaternary age, although they did not occur synchronously along the margins of the Balearic Basin, represent an estimated minimum volume of 
$400 \mathrm{~km}^{3}$, attesting to major episodes of instability at the end of the Quaternary (around the LGM and the following deglacial period).

Similar but buried mass-transport deposits are known in the Gulf of Lions and on the Iberian margin. Under the Petit-Rhône Fan, mass-transport bodies are interstratified between the middle and upper complexes (complexes 2 and 3), on both levees of the middle complex and inside the channel (Droz and Bellaiche 1985) (Fig. 4), suggesting that sediment instability has been a recurrent phenomenon throughout the Quaternary. In the present state of knowledge, without age assignment, the origin, age and recurrence during the Quaternary of such huge mass-transport events cannot be specified. On the Catalan margin, Lastras et al. (2004) identified several debris flow events under the Big'95 debris flow. The biggest one rests on a seismic reflector $(G)$ that separates the Pliocene from the Quaternary deposits, and is therefore probably older than those in the area of the Rhône Fan where the buried mass-transport deposit rests on the middle complex and would therefore be Middle Quaternary in age (see above).

\section{The Balearic Abyssal Plain "Megaturbidite"}

Rothwell et al. (1998, 2000) described an approximately 9 m thick seismically transparent unit of turbidites, called the "Megaturbidite", at about $10 \mathrm{~m}$ below seafloor infilling the deepest part of the Balearic Basin. This megaturbidite was interpreted as a single depositional event (Rothwell et al. 1998). However more recent seismic data provided evidences for possibly at least 2 successive episode of deposition (Droz et al. 2003). This unit is thought to extend in the centre of the basin, bounded by the $2800 \mathrm{~m}$ isobath, representing a total estimated surface of $60000 \mathrm{~km}^{2}$ and a volume of about $500 \mathrm{~km}^{3}$. Recent bathymetric and seismic survey (Droz et al. 2003) refined the north-western boundary of the transparent unit to a water depth of about $2850 \mathrm{~m}$. This megaturbidite was sampled by 5 Calypso cores taken with the R/V Marion Dufresne (cruise 81, 1995), up to $32 \mathrm{~m}$ long, located on a north-south transect from seaward of the Petit-Rhône Fan to the Algerian Margin (Fig. 1). The megaturbidite is composed of AMS radio-carbon dating in hemipelagic intervals bounding the megaturbidite, gave ages of about 17.6 ka B.P. at the top and about $20.3 \mathrm{ka}$ B.P. at the bottom (Rothwell et al. 1998; Hoogakker et al. 2004), indicating that the megaturbidite event was of short duration (2 ka) and deposited sediments at a rate of $3 \mathrm{~m} / \mathrm{ka}$ during the Last Glacial Maximum (beginning of stage MIS2).

The megaturbidite is included into a lithological unit at least $30 \mathrm{~m}$ thick made of upward fining sequences (basal sands, silt to thick structureless muds) interpreted as a succession of ponded turbidite deposits, intercalated with thinner bioturbated foraminifer-rich mud intervals of hemipelagic origin. In the Calypso cores, turbidites account for about $90 \%$ of the sediment column, with a percentage increase towards the north. This northward evolution is also emphasized by the coarsening of basal sands in the megaturbidite in the northward direction, suggesting that sediments in the megaturbidite possibly originated from the northern parts of the basin (Gulf of Lions via the Petit-Rhône or Sète Canyon, Catalan Margin, Ligurian Margin via the Var Valley or Corsican Margin). Preliminary analysis of recent seismic data (Ferrer 2004) did not reveal any physical continuity of the megaturbidite with any of the northern and western seismic bodies (neither the Rhône Fan, the Western Mass-Transport Deposit, nor the Valencia Fan). Very high-resolution seismic profiles indicate that the transparent unit is intercalated between the distal Rhône Fan (that became inactive around 20 ka B.P. at water depth greater than $2000 \mathrm{~m}$, Méar 1984) and the Valencia lobe that is Late Pleistocene-Holocene according to Limonov et al. (1995). More precise origin for the material accumulated in the megaturbidite remains unknown. However, in the basinal turbidites that cover the megaturbidite, analysis of clay minerals of sediments collected in short cores from the Balearic Basin (Méar 1984) indicates a rhodanian origin of the inputs, possibly through the Grand-Rhône River and canyon head where the suspended material is concentrated during the Holocene (Aloïsi et al. 1982). 


\section{IV-Quaternary sedimentary evolution of the northern Balearic Basin}

This synthesis allows a recapitulation of the sedimentary evolution of the northern Balearic Basin during the Quaternary. The known or inferred ages for the different sedimentary systems are summarized in Fig. 5.

\section{Pleistocene}

Following the building of the Pliocene basal complex of the Rhône Fan, huge turbidite sedimentation occurred during the Pleistocene and led to aggradation and progradation of thick turbidite systems (up to $1300 \mathrm{~m}$ thick) linked to the main canyons or convergent system of canyons on the Gulf of Lions margin.

From indirect estimation, the building of the southern part of the upper complex of the PetitRhône Fan ended around 20 ka B.P., in response to instability of the levees and the lower continental slope inducing mass-transport events that probably were of short duration. During this episode of instability, collapse of the levees inside the main channel blocked the channel and induced its avulsion. Renewed aggrading activity occurred leading to the construction of the small channel/levee system of the Neofan on top of its avulsion lobe. The starvation of the Neofan probably relates to the progressive disconnection of the Rhône River and Petit-Rhône Canyon as the sea level was rising following the Last Glacial Maximum (MIS 2), and the definitive abandonment of the fan occurred 4 ka later upstream from the bifurcation point.

Distal turbidites accumulated in the Balearic Basin as a $9 \mathrm{~m}$ thick megaturbidite bed between 20.3 and 17.6 ka B.P., approximately at the time when the architecture and evolution of the Rhône Fan was strongly modified by instability processes that resulted in the shift of depocenters toward the Neofan. However, because of uncertainties about the age of these events, there is no clear relationship between the accumulation of the megaturbidite and either the mass-transport processes or the turbidite processes.

\section{5 ka B.P. to present}

During the deglacial period, the turbidite activity progressively diminished as sea-level rose. Definitive abandonment of the Rhône Fan occurred at 11 ka B. P. However, erosional activity remained in some canyons, until 8 ka B.P. (Sète Canyon) and 4 ka B.P. (La Fonera Canyon) (Droz et al. 2001) and resulted in the re-deposition of eroded sediments as very thin unchannelized lobes at the outlet of the canyons. In addition, new hydrodynamic data obtained in the framework of the EUROSTRATAFORM programme show that some canyons of the Gulf of Lions (Cap de Creus, Lacaze-Duthiers and Petit-Rhône Canyons) are presently registering strong currents (e.g. Fabres et al. 2005).

\section{-Conclusions}

Thanks to numerous results obtained over the last 20 years of research in the Gulf of Lions and northern Western Mediterranean, the Plio-Quaternary sedimentary evolution of the southern margin of France is now among the best known in the world. However, our knowledge of this margin is still lacking a good chronostratigraphy to constrain the general evolution and to precisely determine the main factors that controlled sedimentation during the Quaternary.

New data from the PROMESS 1 drilling cruise (june 2004: Berné 2004) will bring some of that stratigraphic constraints for the last 500 ka (Upper Quaternary) on the outer shelf and upper slope. Despite mass-movements that affect most of the continental slope, it is hoped to utilize high-resolution multi-channel seismic profiles across the margin to tie in the precise chronostratigraphic framework of Promess 1 to the turbiditic depositional sequences along the continental rise. 


\section{References}

Aloïsi J-C, Cambon J-P, Carbonne J, Cauwet G, Millot C, Monaco A, Pauc H (1982) Origine et rôle du néphéloïde profond dans le transfert des particules au milieu marin. Application au Golfe du Lion. Oceanologica Acta 5(4): 481-491

Alonso B, Maldonado A (1990) Late Quaternary sedimentation patterns of the Ebro turbidite systems (northwestern Mediterranean): two styles of deep-sea deposition. Marine Geology 95: 353-377

Alonso B, Ercilla G (2002) Architecture of modern turbidite systems in different geologic settings on the Spanish margins (NW and SW Mediterranean Sea). In: F. Briand (ed), Turbidite systems and deep-sea fans of the Mediterranean and Black seas. CIESM Workshops Series 17: 120

Alonso B, Canals-Artigas M, Got H, Maldonado A (1991) Sea valleys and related depositional systems in the Gulf of Lions and Ebro continental margins. American Association of Petroleum Geologists Bulletin 7: 1195-1214

Alonso B, Canals M, Palanques A, Réhault J-P (1995) A deep-sea channel in the Northwestern Mediterranean Sea: morphology and seismic structure of the Valencia Channel and its surroundings. Marine Geophysical Researches 17: 469-484

Amblas D, Canals M, Urgeles R, Lastras G, Hughes-Clarke JE (2004) The ocean margin northeast of Iberia: a complex sedimentary system draining into the deep basin. Joint EURODELTA-EUROSTRATAFORM Annual Meeting, 20-23 October 2004, Abstract volume, p. 25

Baztan, J (2004). Formation et évolution des canyons sous-marins du Golfe du Lion: relations avec les cycles glacio-eustatiques. Thesis of University of Brest, Brest, France, 417 pp.

Baztan J, Berné S, Olivet J-L, Rabineau M, Aslanian D, Gaudin M, Réhault J-P, Canals M (2005) Axial incision: the key to understand submarine canyon evolution. Marine and Petroleum Geology 22: 805-826

Beaudouin C, Dennielou B, Melki T, Guichard F, Kallel N, Berné S, Huchon A (2004) The Late-Quaternary climatic signal recorded in a deep-sea turbiditic levee (Rhône Neofan, Gulf of Lions, NW Mediterranean): palynological constraints. Sedimentary Geology 172: 85-97

Bellaiche G, Coutellier V, Droz L (1986) Seismic evidence of widespread mass transport deposits in the Rhône deep-sea fan: their role in the fan construction. Marine Geology 71:327-340

Bellaiche G, Coutellier V, Droz L (1989) Detailed morphology, sedimentary structure and evolution of the continental margin of the Western Provençal Bassin (south of France) since late Miocene. Marine Geology 89: 259-268

Berné S (2004) PROMESS 1: Past Global Changes Investigated by Drilling Mediterranean Continental Margins. AGU Fall Meeting, 13-17 December 2004, San Francisco, CA

Berné S, Loubrieu B, Equipe Calmar embarquée (1999) Canyons et processus sédimentaires récents sur la marge occidentale du Golfe du Lion. Premiers résultats de la campagne Calmar. Comptes Rendus de l'Académie des Sciences Paris, Sciences de la Terre et des Planètes 328: 471-477

Berné S, Carré D, Loubrieu B, Mazé J-P, Normand A (2001). Carte morpho-bathymétrique du Golfe du Lion. Ifremer-Région Languedoc-Roussillon, Brest

Berné S, Aloïsi J-C, Baztan J, Dennielou B, Droz L, dos Reis TA, Lofi J, Méar Y, Rabineau M (2002) Notice de la carte morpho-bathymétrique du Golfe du Lion. IFREMER et Région Languedoc Roussillon, Brest, 48 pp. 
Bonnel C (2001) Faciès sismiques, lithologiques et modes de mise en place du néofan du Rhône et du corps discordant occidental du Golfe du Lion (Méditerranée Occidentale). DEA, University Bordeaux 1, 54 pp.

Bonnel C, Dennielou B, Droz L, Mulder T, Berné S (2005) Architecture and depositional pattern of the Rhône Néofan and recent gravity activity in the Gulf of Lions (Western Mediterranean). Marine and Petroleum Geology, 22: 827-843

Canals M, Casamor JL, Urgeles R, Lastras G, Calafat AM, De Batist M, Masson DG, Berné S, Alonso B (2000) The Ebro continental margin, Western Mediterranean Sea: Interplay between canyon-channel systems and mass wasting processes. Gulf Coast Section-SEPM Foundation 20th Annual Bob F. Perkins Research Conference on "Deep-water reservoirs of the world", December 2000, Houston, Texas, pp. 20

Chamley H (1971) Recherches sur la sédimentation argileuse en Méditerranée. Doctorat d'Etat, University AixMarseille, 401 pp.

Clauzon G, Rubino JL, Savoye B (1995) Marine Pliocene Gilbert-type fan deltas along the French Mediterranean coast. A typical infill feature of preexisting subaerial Messinian canyons. 16th IAS Regional Meeting of Sedimentology-5ème Congrès Français de Sédimentologie, Field trip guide book, ASF Publication, Paris, 23: 145-222

Comas MC, Zahn R, Klaus A et al. (1999) Proc. ODP, Initial Reports Leg 161: College Station, TX (Ocean Drilling Program)

Conchon O (1992) Que sont Günz et Mindel devenus ? Approches récentes de la stratigraphie du Quaternaire. Geochronique 44: 16-18

Coutellier V (1985) Mise en Evidence et Rôle des Mouvements Gravitaires dans l'Evolution de la Marge Continentale: exemple des Marges du Golfe du Lion et de la Provence Occidentale. $3^{\text {rd }}$ Thesis, University Paris VI, 189 pp.

dos Reis AT (2001) La tectonique salifère et son influence sur l'architecture sédimentaire quaternaire de la marge du Golfe du Lion - Méditerranée Occidentale. Thesis of University Paris VI, 2 volumes, 372 pp.

dos Reis AT, Gorini C, Mauffret A, Mepen M (2004a) Stratigraphic architecture of the Pyreneo-Languedocian submarine fan, Gulf of Lions, Western Mediterranean sea. Comptes Rendus Geosciences 336: 125-136

dos Reis AT, Gorini C, Mauffret A, Wiebull WW (2004b) Salt tectonics, a controlling factor on the development of the Marseille and Grand-Rhône sedimentary ridges, Gulf of Lions, Western Mediterranean sea. Comptes Rendus Geosciences 336: 143-150

dos Reis AT, Gorini C, and Mauffret A (2005) Implications of salt-sediment interactions on the architecture of the Gulf of Lions deep-water sedimentary systems - Western Mediterranean Sea. Marine and Petroleum Geology 22: 713-746

Droz L (1983) L’éventail sous-marin profond du Rhône (Golfe du Lion): grands traits morphologiques et structure semi-profonde. 3rd Cycle Thesis, University Paris VI, 195 pp.

Droz L (1991) Les éventails sous-marins profonds : structure et évolution sédimentaire, à partir de l'étude comparative de trois édifices, l'Eventail du Rhône, la Ride du Var, le Cône de l'Indus. Habilitation à Diriger des Recherches, University Paris VI, 254 pp.

Droz L, Bellaiche G (1985) Rhône deep-sea fan: morphostructure and growth pattern. American Association of Petroleum Geologists Bulletin 69: 460-479

Droz L, Loubrieu B, Berné S, Cochonat P, CALMAR Shipboard Scientific Party (1998) Turbidites of the Western Golfe du Lion: relationships between Pyreneo-Languedocian and Rhone inputs. European Geophysical Society, 23rd General Assembly, 20-24 April 1998, Nice 
Droz L, Kergoat R, Cochonat P, Berné S (2001) Recent sedimentary events in the western Gulf of Lions (Western Mediterranean). Marine Geology 176: 23-37

Droz L, Rabineau M, Shipboard Scientific Party (2003) Interrelationships between the sedimentary systems in the Western Mediterranean (Gulf of Lions and Balearic Abyssal Plain): preliminary results from PROGRES cruise (EUROSTRATAFORM programme). Ocean Margin Research Conference, Omarc, 1517 September 2003, Paris, p. 130

Droz L, Dennielou B, Bonnel C, Berné S, Ferrer P, Jegou I, PROGRES Team (2004) The southern prolongation of the Rhône Neofan from recent high-resolution data (PROGRES cruise, EUROSTRATAFORM/WP3). EUROSTRATAFORM 2nd Annual Meeting, 20-23 October 2004, Venice, Italy

Fabres J, Miserocchi S, Heussner S, Calafat AM, Zuniga D, Canals M, Tesi T, Puig P, Palanques A, Durrieu de Madron X (2005) The impact of the December 2003 catastrophic storm on near bottom particle fluxes at canyon heads in the Gulf of Lions. European Geosciences Union, General Assembly, 24-29 April 2005, Vienna, Austria, Geophysical Research Abstracts 7: 09225

Ferrer P (2004) Chronologie relative des systèmes turbiditiques dans la partie distale du Golfe du Lion (Méditerranée Occidentale) sur les derniers 200.000 ans. Master 2 Degree Report, University of Brest, UBO, Brest, France: 49 pp.

Field ME, Gardner JV (1990) Pliocene-Pleistocene growth of the Rio Ebro margin, northeast Spain: a prograding-slope model. Geological Society of America Bulletin 102: 721-733

Gaudin M, Cirac P, Berné S, Mulder T, Bourillet JF, Cremer M (2003) Sédimentation récente dans les têtes des canyons de Capbreton (Golfe de Gascogne) et Bourcart (Golfe du Lion). $9^{\text {ème }}$ Congrès de l'Association des Sédimentologistes Français. Abstract Book, ASF Publication 38: 541

Gautier F, Clauzon G, Suc J-P, Cravatte J, Violanti D (1994) Age et durée de la crise de salinité messinienne. Comptes Rendus de l'Académie des Sciences de Paris 318: 1103-1109

Gorini C (1993) Géodynamique d’une marge passive: le Golfe du Lion (Méditerranée occidentale). 3rd Cycle Thesis, University Paul Sabatier-Toulouse 3, Toulouse, 256 pp.

Gorini C, Lofi J, Duvail C, dos Reis AT, Guennoc P, Lestrat P, Mauffret A (2005) The Late Messinian salinity crisis and Late Miocene tectonism: interaction and consequences on the physiography and post rift evolution of the Gulf of Lions margin. Marine and Petroleum Geology 22: 695-712

Guennoc P, Gorini C, Mauffret A (2000) Histoire géologique du Golfe du Lion et cartographie du rift oligoaquitanien et de la surface messinienne. Géologie de la France 3: 67-97

Hoogakker BAA, Rothwell RG, Rohling EJ, Paterne M, Stow DAV, Herrle JO, Clayton T (2004) Variations in terrigenous dilution in western Mediterranean Sea pelagic sediments in response to climate change during the last glacial cycle. Marine Geology 211: 21-43

Hsü KJ, Montadert L et al. (1978) Initial Reports of the Deep-Sea Drilling Project, 42A, US Govt. Printing Office, Washington, DC, 1249 pp.

Jallet L, Giresse P (2005) Construction of the Pyreneo-Languedocian sedimentary ridge and associated sediment waves in the deep western Gulf of Lions (Western Mediterranean). Marine and Petroleum Geology 22: 865-888

Kenyon NH, Droz L, Ivanov MK, Millington J (1995) Scour holes in a channel-lobe transition zone on the Rhône Cone. In: Pickering KT, Hiscott RN, Kenyon NH, Ricci Lucchi F, Smith RDA (eds) Atlas of Deep Water Turbidite Systems, Chapman Hall, London, pp 212-215 
Krijgsman W, Hilgen FJ, Raffi I, Sierro FJ, Wilson DS (1999) Chronology, causes and progression of the Messinian salinity crisis. Nature 400: 652-655

Kukla G, Cilek V (1996) Plio-Pleistocene megacycles: record of climate and tectonics. Palaeogeography, Palaeoclimatology, Palaeoecology 120: 171-194

Lastras G, Canals M, Hughes-Clarke JE, Moreno A, De Batist M, Masson DG, Cochonat P (2002) Seafloor imagery from the BIG’95 debris flow, western Mediterranean. Geology 30: 871-874

Lastras G, Canals M, Urgeles R, De Batist M, Calafat AM, Casamor JL (2004) Characterisation of the recent BIG'95 debris flow deposit on the Ebro margin, Western Mediterranean Sea, after a variety of seismic reflection data. Marine Geology 213: 235-255

Limonov AF, Kenyon NH, Ivanov MK, Woodside JM (1995) Deep-sea depositional systems of the Western Mediterranean and mud volcanism on the Mediterranean Ridge; Initial results of geological and geophysical investigations during the fourth UNESCO-ESF "Training-Through-Research" cruise of R/V Gelendzhik (June-July, 1994), UNESCO Reports in Marine Science 67: 171 pp.

Lofi J, Gorini C, Berné S, Clauzon G, dos Reis AT, Ryan WBF, Steckler MS (2005) Erosional processes and paleo-environmental changes in the western Gulf of Lions (SW France) during the Messinian Salinity Crisis. Marine Geology 217: 1-30

Marsset T, Bellec V (2002) Late Pleistocene-Holocene deposits of the Rhône inner continental shelf (France): detailed mapping and correlation with previous continental and marine studies. Sedimentology 49: 255276

Méar Y (1984) Séquences et unités sédimentaires du glacis rhodanien (Méditerranée Occidentale). $3^{\text {rd }}$ Cycle Thesis, University of Perpignan, Perpignan, France, 234 pp.

Menard HW, Smith SM, Pratt RM (1965) The Rhône Deep-Sea Fan. In: Whittard WF, Bradshaw R (eds), Submarine geology and geophysics. Butterworths, London, pp 271-285

Monjuvent G (1984) Paléogéographie quaternaire, planches Q1 à Q4. In: Debraband-Passard S, Courbouleix S (eds), Synthèse Géologique du Sud-Est de la France. Mémoire BRGM 125/126: 565-567

Morris SA, Kenyon NH, Limonov AF, Alexander J (1998) Downstream changes of large-scale bedforms in turbidites around the Valencia channel mouth, north-west Mediterranean: implications for palaeoflow reconstruction. Sedimentology 45: 365-377

Olivet JL (1996) Cinématique de la plaque Ibérique. Bulletin du Centre de Recherches Exploration-Production Elf-Aquitaine 20:131-195

Paillard D (2001) Glacial cycles: toward a new paradigm. Reviews of Geophysics 39: 325-346

Palanques A, Kenyon NH, Alonso B, Limonov A (1995) Erosional and depositional patterns in the Valencia Channel mouth: an example of a modern channel-lobe transition zone. Marine Geophysical Researches 17: 503-517

Pirmez C, Hiscott RN, Kronen JD Jr. (1997) Sandy turbidite successions at the base of channel-levee systems of the Amazon Fan revealed by FMS and cores: unraveling the facies architecture of large submarine fans. In: Flood RD, Piper DJW, Klaus A, Peterson LC (eds) Proceedings of the Ocean Drilling Program, Scientific Results: College Station, TX (Ocean Drilling Program) 155: 7-33

Rabineau M (2001) Un modèle géométrique et stratigraphique des séquences de dépôts quaternaires sur la marge du Golfe du Lion: enregistrement des cycles climatiques de 100000 ans. Thesis of University of Rennes 1, Rennes, France 
Rothwell RG, Thomson J, Kähler G (1998) Low sea-level emplacement of a very large Late Pleistocene "megaturbidite" in the western Mediterranean Sea. Nature 392: 377-380

Rothwell RG, Reeder MS, Anastasakis G, Stow DAV, Thomson J, Kähler G (2000) Low sea-level emplacement of megaturbidites in the western and eastern Mediterranean Sea. Sedimentary Geology 135: 75-88

Ruddiman WF, McIntyre A, Raymo M (1986) Paleoenvironmental results from North Atlantic sites 607 and 609. In: Ruddiman WF, Kidd RB, Thomas E et al. (eds), Initial Reports of the Deep Sea Drilling Project, Washington, 94, part 2: 855-878

Ryan WBF, Hsü KJ et al. (1973) Initial Reports of the Deep-Sea Drilling Project, 13 (1-2), US Govt. Printing Office, Washington, DC, 1447 pp.

Savoye B, Piper D, Droz L (1993) Plio-Pleistocene evolution of the Var deep-sea fan off the French Riviera. Marine and Petroleum Geology 10: 550-571

Showers JW, Schneider R, Mikkelsen N, Maslin M (1997) Isotopic stratigraphy of Amazon fan sediments. In: Flood RD, Piper DJW, Klaus A, Peterson LC (eds) Proceedings of the Ocean Drilling Program, Scientific Results: College Station, TX (Ocean Drilling Program) 281-303

Smith WHF, Sandwell DT (1997) Global sea floor topography from satellite altimetry and ship depth soundings. Science 277: 1956-1962

Speranza F, Villa IM, Sagnotti L, Florindo F, Cosentino D, Cipollari P, Mattei M (2002) Age of the CorsicaSardinia rotation and Liguro-Provençal Basin spreading: new paleomagnetic and $\mathrm{Ar} / \mathrm{Ar}$ evidence. Tectonophysics 347(4): 231-251

Stuiver M, Reimer PJ, Bard E, Beck JW, Burr GS, Hughen KA, Kromer B, McCormac G, van der Plicht J, Spurk M (1998) INTCAL98 radiocarbon age calibration, 24,000-0 cal BP. Radiocarbon 40 (3): 10411083

Torres J (1995) Analyse détaillée du transfert de sediment du continent vers le basin: le Quaternaire terminal au large du delta du Rhône (Méditerranée nord-occidentale). $3^{\text {rd }}$ Cycle Thesis, University of Brest, 353 pp.

Torres J, Droz L, Savoye B, Terentieva E, Cochonat P, Kenyon NH, Canals M (1997) Deep-sea avulsion and morphosedimentary evolution of the Rhône Fan Valley and Neofan during the Late Quaternary (northwestern Mediterranean Sea). Sedimentology 44: 457-477

Van Eysinga FWB, Haq BU (1987) Geological time table-3 $3^{\text {rd }}$ edition. Elsevier Science Publishers, Amsterdam 


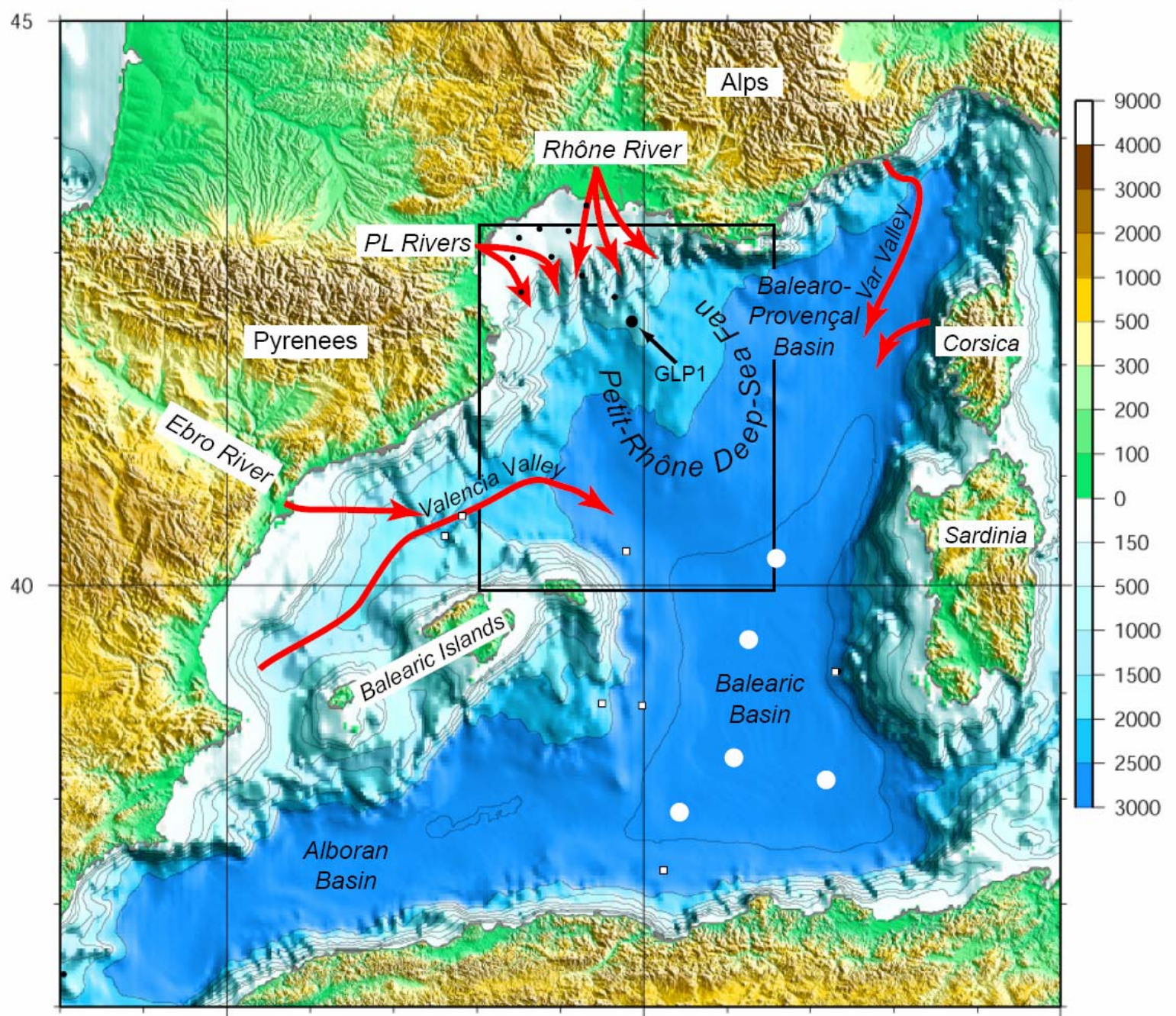

Fig. 1: Bathymetry of the Western Mediterranean (contour isolines: 150, 300, 500, 1000, 1500, 2000, 2500 and $2800 \mathrm{~m}$ ) and topography of surrounding lands. The square indicates the location of the synthetic map shown in figure 3. Arrows: origin of inputs to the Balearic and Balearo-Provençal Basins (PL Rivers: Pyreneo-Languedocian rivers). Black dots: Industrial boreholes (including GLP1 mentioned in text), white squares: drilling sites of ODP Leg 13 (Ryan et al., 1973), white dots: Calypso cores in the Balearic Basin (Rothwell et al., 1998). Bathymetric data from Smith and Sandwell (1997), Topography from GTOPO30 (U.S. Geological Survey's EROS Data). Realization M. Rabineau (UBO) and D. Aslanian IFREMER Brest. 


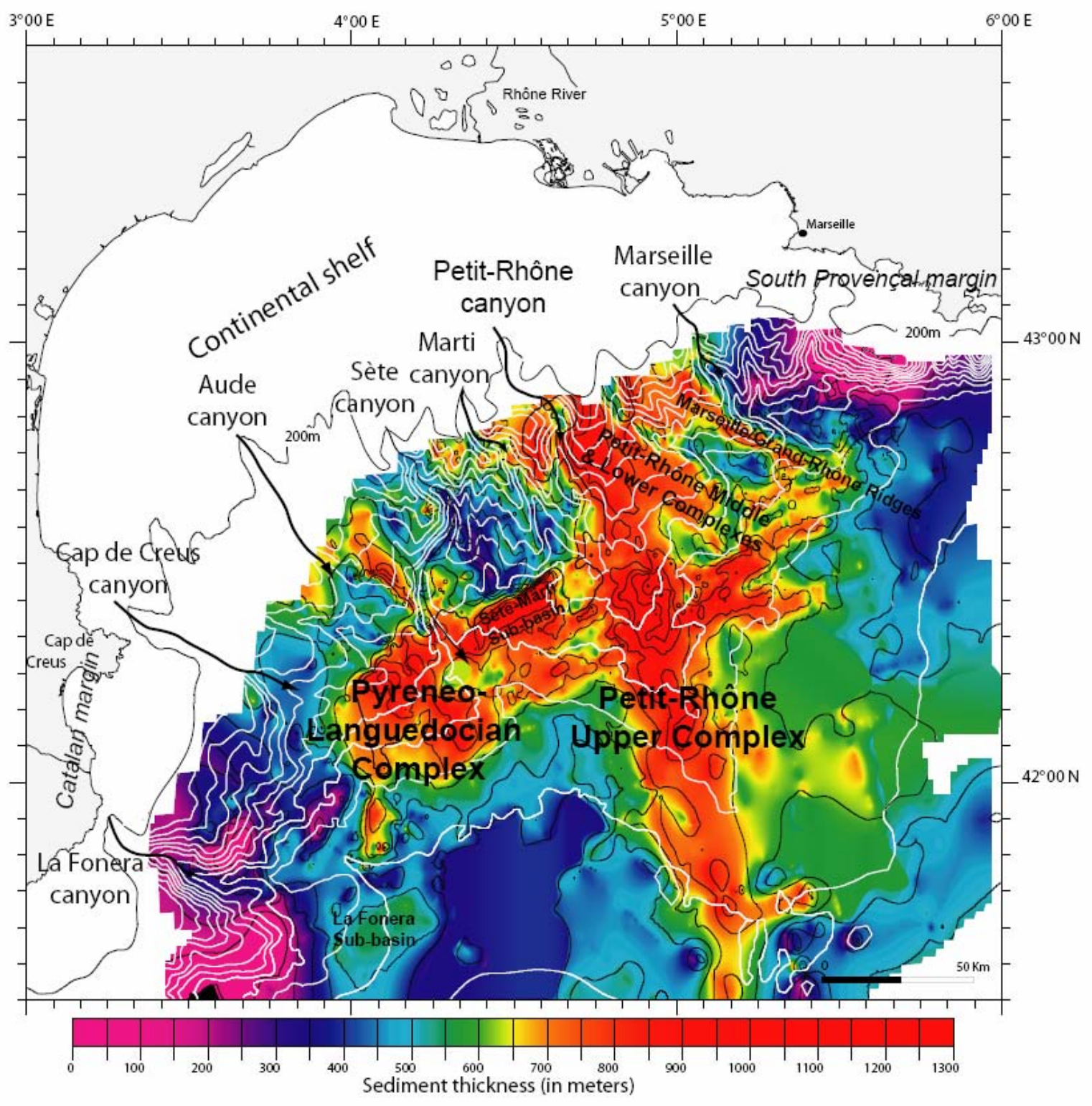

Fig. 2: Thickness of Quaternary sediments on the slope and rise of the Gulf of Lions. Slightly modified from dos Reis et al. (2005). 


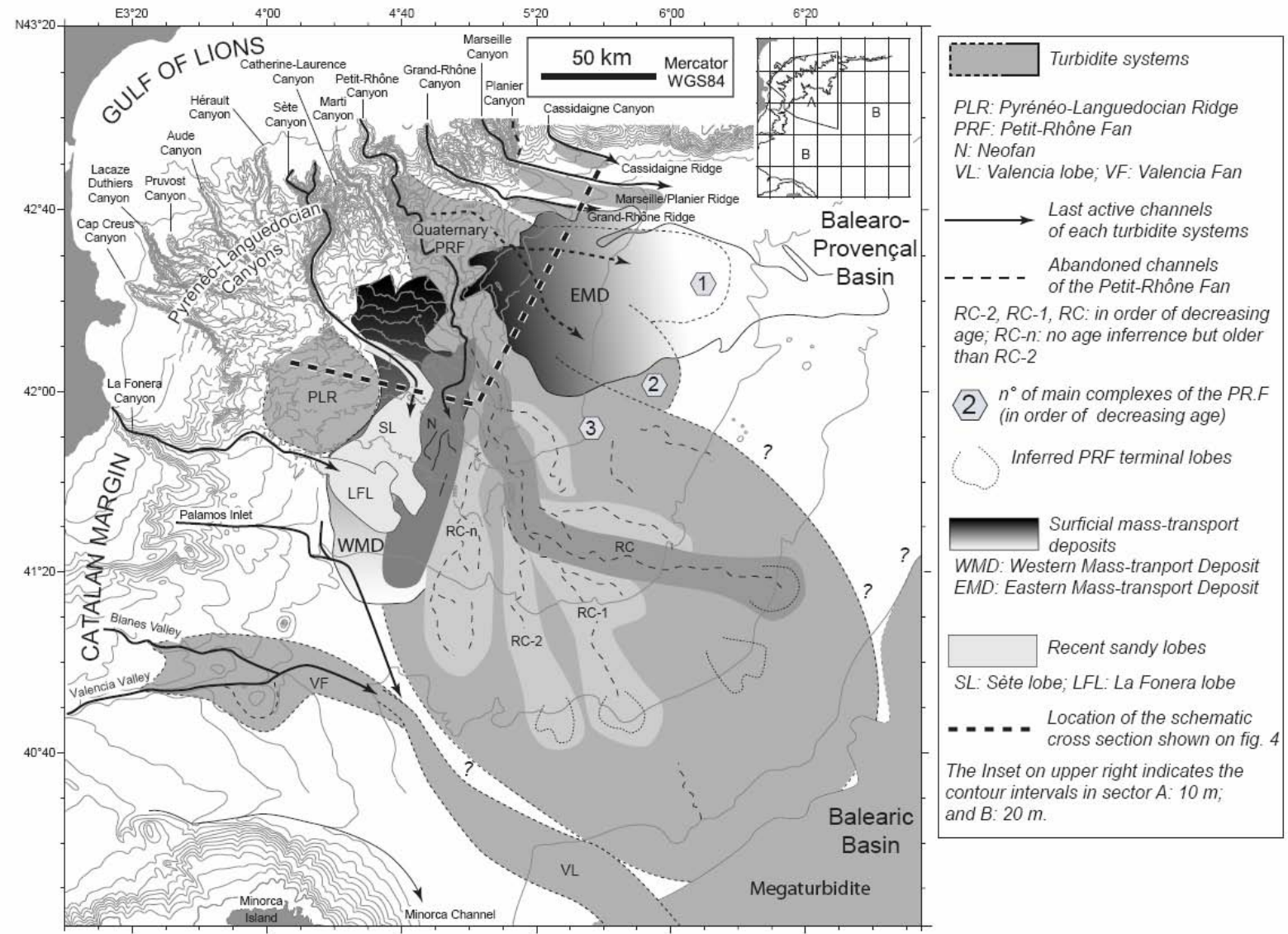

Fig. 3: Synthetic map showing the main sedimentary systems in the northern Balearic Basin and western Balearo-Provençal Basin. Most of the sediments originate from the southern margin of France, via the Rhône River that brings Alpine continental inputs to the Gulf of Lions, and the smaller Pyreneo-Languedocian Rivers that mainly drain the Pyrenees. The principal turbidite system is the Petit-Rhône Fan that extends basinwards up to the northern limit of the Balearic Basin. Synthesis mainly based on Droz and Bellaiche (1985), dos Reis (2001), dos Reis et al. (2005) for the Gulf of Lions turbidite systems; Droz et al. (2001, 2003, 2004) and Bonnel et al. (2005) for the Neofan and recent Sète and La Fonera sandy lobes; Palanques et al. (1994) for the Valencia Fan.

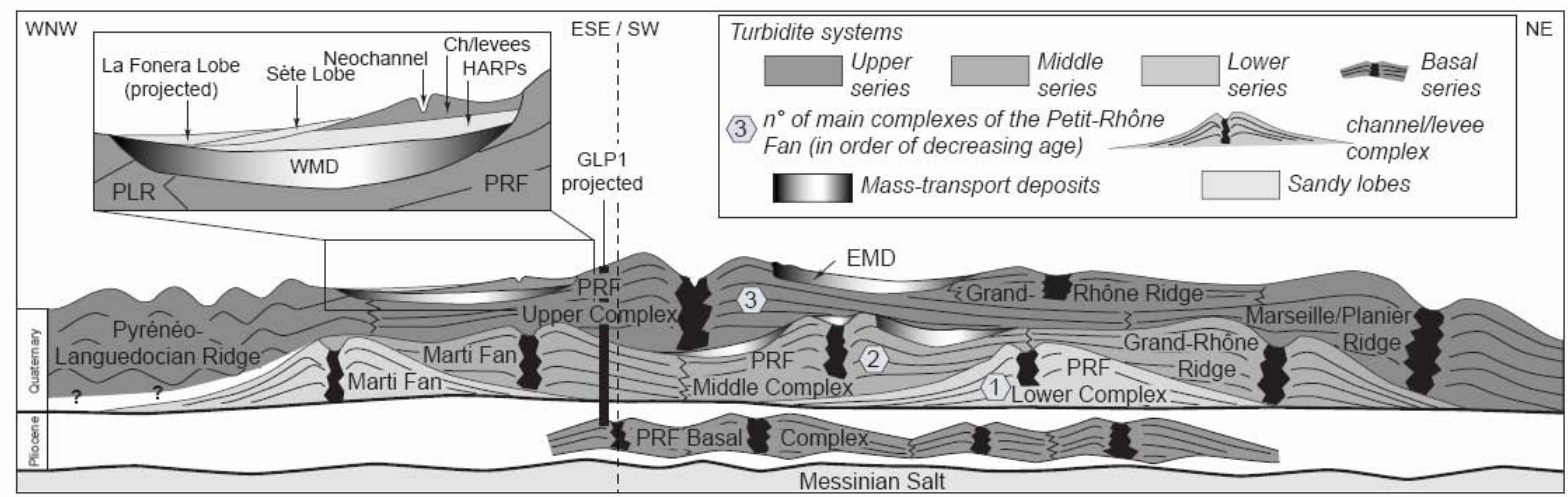

Fig. 4: Schematic cross section on the rise of the Gulf of Lions (see figure 3 for approximate location), showing the Plio-Quaternary sedimentary architecture of the margin and stacking pattern of the turbidite systems and mass-transport deposits. Ages are inferred from industrial boreholes (GLP1, courtesy of Total, in Droz 1991 and dos Reis 2001). Redrawn and modified from dos Reis et al. (2005) to illustrate the mass transport deposits and the most recent sedimentary events (Neofan and Sète and La Fonera sandy lobes). Not to scale. 


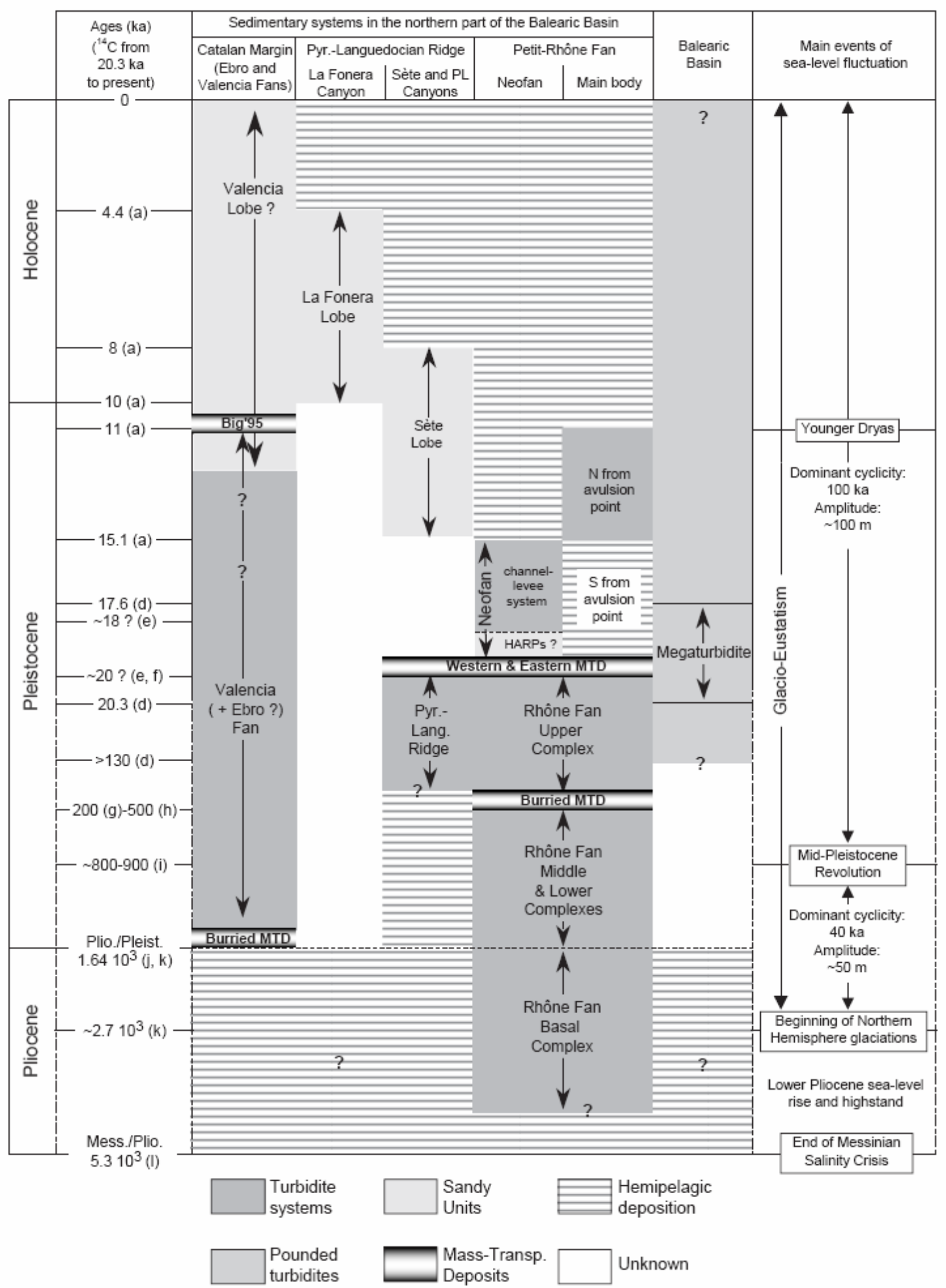

Fig. 5: Synthesis of the ages known from coring or inferred from correlations for the main sedimentary systems of the Northern Balearic Basin. References for age attribution: (a): Bonnel et al. 2005, (b): Lastras et al. 2002, 2004, (c): Méar 1, (d): Hoogakker et al. 2004, (e): proposed in this study, (f): Méar 1984, (g): Bellaiche et al. 1989, (h): e.g. Van Eysinga and Haq 1987, Kukla and Cilek 1996, (i): e.g. Ruddiman et al. 1986, Paillard 2001, (j): GLP1 borehole in Droz 1991 and dos Reis et al. 2005, (k): e.g. Conchon 1992, (l): e.g. Gautier et al. 1994, Krijgsman et al. 1999. 
Table 1: ${ }^{14} \mathrm{C}$ dates cited in the text and corresponding calendar ages when published

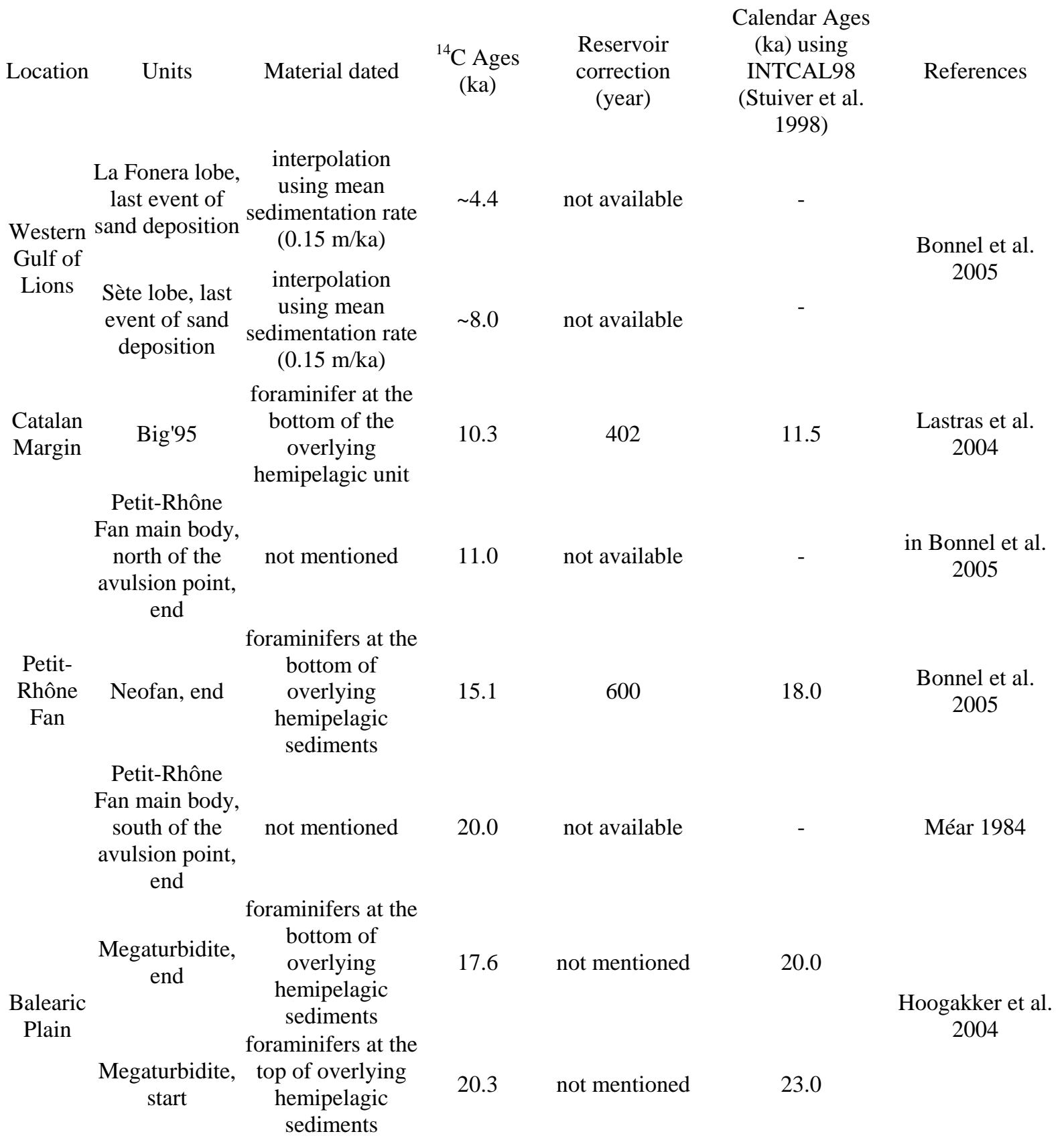

